\title{
EDITORIAL: THE QUEST FOR HUMANITY 150 YEARS OF INTERNATIONAL HUMANITARIAN LAW AND ACTION
}

150 years ago, ideas were set in motion that heralded a new era of international solidarity. The creation of the International Committee of the Red Cross (ICRC) in 1863 and the adoption of the first Geneva Convention the following year mark the birth of modern international humanitarian law and action. The ICRC, together with its partners from what has become a universal the Red Cross and Red Crescent Movement (the Movement), endeavours to reach out to victims of armed conflicts and other situations of violence - from Syria to Afghanistan, from the Democratic Republic of the Congo to Colombia. With its over 13,000 employees active in more than eighty countries around the world, the ICRC uses a wide range of professional expertise in domains as diverse as law, advocacy, engineering, war surgery, sanitation and logistics.

The institution strives to provide humanitarian aid and protection response not only in some of the most mediatised crises of the day, but also in many of today's forgotten ones. While still relying on time-tested principles and methods, it continues to develop new, pragmatic responses to the ever-changing realities of war and violence.

In addition to the Movement, and following 150 years of progressive development, hundreds of NGOs and international organisations supported by public and private donors form the humanitarian sector today. From a purely Western enterprise, this sector is becoming increasingly diverse and multipolar.

After 150 years of a discrete yet persistent and sometimes obstinate presence in the most hostile environments-all violent zones of the modern era - one can only wonder at the longevity of the ICRC. What are the reasons that have made the organisation stand the test of time? What are the dynamics at work in the development of this humanitarian endeavour? How is the role of the organisation perceived by key players of the international community? How can the ICRC learn from its history to prepare for the future? These questions have guided us in the preparation of the anniversary issue of the International Review of the Red Cross.

Looking first at the state of the world at the time of the creation of the ICRC and the Movement, we will measure in what ways the project of the founders was forward-looking and how their initial impulse allowed for the continuous development and adaptation of the organisation throughout the years while remaining faithful to the same core ideal. Finally, we will explore some of the main challenges that the ICRC faces today. 


\section{The world at the time of the creation of the ICRC}

'Murderous refinements of war should have correlative refinements of mercy.' ${ }^{\prime}$ As illustrated by this early quote from two of the founders of the ICRC, there was a very early recognition that the unprecedented period of progress that the world was entering into was also creating new dangers and that it was necessary to anticipate and manage new risks.

\section{The acceleration of scientific and technological progress}

Even though life in the nineteenth century was arguably harsher and more precarious than today for the vast majority of people, it seems that this period of time was also a moment of acceleration in scientific and social progress, a transition between an old immutable order and a new era of fast changes that continues until today. Ground-breaking discoveries were taking place in every domain, opening the way for unprecedented developments.

In 1863, the very limits of our own world had not yet been fully delineated: the explorers Speke and Grant located Lake Tanganyika and Lake Victoria that same year, and it was eventually proved to be the latter from which the river Nile flowed. In 1859, Darwin published his theory of evolution in his book On the Origin of Species; humanity itself was an uncharted territory that was yet to be explored.

At the same time, the world seemed smaller and smaller as transportation and communication technologies evolved: by 1863, the industrial revolution had spread from the United Kingdom to the rest of Europe and North America. The first section of the London underground was opened that year, the International Telegraph Union ${ }^{2}$ was about to be created, and in the United States, the construction of the first transcontinental railway had just started. ${ }^{3}$

\section{The evolution of ideas}

It was also a period of time when new ideas about social organisation, rights, and education were burgeoning and could draw overwhelming support. It seemed that such ideas could become reality for the first time in history, through new forms of social and political structures.

Of course, divisions and inequalities across social classes, religious groups, and genders - many of which persist today - were still deeply rooted in all societies and were sanctioned by law. Prompted by the progress taking place in science and technology, new ideologies were being put forward, offering their own global view of

1 Louis Appia and Gustave Moynier, La guerre et la charité, Cherbuliez, Geneva, 1867, cited in Caroline Moorehead, Dunant's Dream: War, Switzerland and the History of the Red Cross, Carroll \& Graf, New York, 1999, p. 51.

2 Now known as the International Telecommunication Union, a UN specialised agency.

3 It would eventually be completed in 1869. 
how humanity should be organised. Some of these ideologies would shape the history of the next century, sometimes with the most tragic consequences. ${ }^{4}$

In 1865, the United States, following many other nations, formally abolished slavery. ${ }^{5}$ Despite such progress, colonial expansion was at its beginning. 'Humanity' was still very much a concept that applied narrowly only to the inhabitants of the so-called 'civilised' world, even though 'charitable' pretexts would later be used to justify the colonial enterprise. Until today, the humanitarian endeavour is often received with suspicion against a perceived Western imperialism.

Nonetheless, the struggle for political, social, and economic rights had started, inspired by the egalitarian ideas of the French Revolution and pioneered by workers in new industrial centres. ${ }^{6}$

\section{An unstable, multipolar world}

Henry Dunant lived in a world in which war was still seen as a heroic enterprise and a perfectly legitimate way to solve international disputes between monarchs and states. The second half of the nineteenth century would be a period of instability and conflict, starting with the Crimean War (1853-1856). At the time of the foundation of the ICRC, the American Civil War (1861-1865) was still raging and France was engaged in a colonial war in Mexico. Europe was still in the process of drawing its own map, and conquest by force was a way to carve territories for new emerging nations. This was soon to be exemplified by the Austro-Prussian war of 1866 and the Franco-Prussian war of 1870, which would lead to the unification of Germany. The decline of the Ottoman Empire, called 'the sick man of Europe', was ongoing, with European powers competing for the spoils. The world had yet to wait more than eighty years and endure two world wars to see the universal prohibition of the use of force in international relations enshrined in the Charter of the United Nations.

\section{The eve of a new era in warfare}

At the end of the eighteenth century, a combination of innovations had started to produce deadly effects on the battlefield, leading to an increased number of casualties - a trend which would eventually culminate during the First World War. First, the conscription system invented during the French Revolution and put in place by all major European powers was creating an immense reservoir of soldiers

4 For instance, Arthur de Gobineau had just published his 'Essay on the inequality of the Human Races' in 1855 - a very early example of pseudo-scientific racism that would later inspire the Nazi ideology. Karl Marx was still working on Das Kapital, (whose first volume would be published in 1867), planting the seeds of communism and indirectly, of an ideological struggle that would divide humanity for decades to come.

5 The Thirteenth Amendment to the United States Constitution abolishing slavery was ratified on 6 December 1865.

6 For instance, it was only in May 1864 that France abolished the criminalisation of strikes and coalitions, de facto authorising the founding of trade unions (Loi Ollivier of 25 May 1864). 
whose lives were considered a disposable commodity. Second, progress in ballistics and explosives allowed for more accurate and more powerful rifles and guns, produced in industrial quantities. Finally, the railroads were enabling the concentration and movement of troops at an unprecedented speed and scale.

During the nineteenth century, battles had turned into mass disaster events in which tens of thousands of men could be injured or killed in a matter of hours. At the same time, the fighting was still limited to a geographically well-defined 'battlefield'. Civilians remained relatively unscathed by its direct effects. For instance, while 46,000 soldiers where put hors de combat (killed, wounded, missing, or captured) in a mere three days of fighting at the battle of Gettysburg in July 1863, only one civilian was killed. This was soon to change, however, and already in 1870 the Franco-Prussian war was having devastating effects on the civilian population.

\section{The birth of international humanitarian action and law}

A few years earlier, Henry Dunant had been appalled by the fate of the wounded left to die in horrific pain in the fields after the battle of Solferino of 1859. Military medical services were completely inadequate and considered a nicety even by the great armies of the time. The fate of the individual soldier simply did not matter. Dunant took improvised measures to organise rescue and care for the wounded on both sides.

Out of his experience on the battlefield, Dunant planted the seeds of the creation of the Red Cross and Red Crescent Movement and international humanitarian law (IHL) in one of the most influential books of the time, A Memory of Solferino. Before the publication of this seminal work, the idea of organising relief and even introducing moderating principles to limit all-out violence in wars had several precursors in many corners of the world. Various religious orders, as well as famous philanthropists such as Florence Nightingale and Clara Barton, had also spontaneously organised medical care and relief to the wounded on the battlefields. Florence Nightingale was already advocating for the reinforcement of military medical services. ${ }^{7}$ The situation was calling for new types of response which would go beyond ad hoc charitable initiatives.

Henry Dunant and the other founders of the Red Cross recognised this and mobilised international support firstly to create a new permanent capacity, independent from states, to assist the wounded soldiers in an impartial and neutral way, and secondly to formulate international obligations that bind states in the treatment of their wounded enemies and of medical or civilian helpers. The creation of the ICRC and the first Red Cross National Societies and the adoption of the First

7 Florence Nightingale, a British nurse, became well-known for her efforts to organise the delivery of medical care to British soldiers in Scutari (Üsküdar) during the Crimean war (1854-1856) and to improve sanitation conditions on the war front. See Cecile Woodham-Smith, Florence Nightingale, 1820-1910, Constable and Company Ltd., London, 1950. C.J. Gill and G.C. Gill, 'Nightingale in Scutari: Her Legacy Reexamined', in Clinical Infectious Diseases, Vol. 40, No. 12, pp. 1799-1805. Clara Barton, the founder of the American Red Cross, pioneered medical relief during the American Civil War, by organising volunteer corps of nurses and doctors to tend to the areas where the war was raging. See Marian Moser Jones, The American Red Cross: from Clara Barton to the New Deal, Johns Hopkins University Press, 2013. 
Geneva Convention one year later mark the birth of international humanitarian action and law. 8

For Dunant and the founders of the Movement, beyond the well-defined and relatively narrow project of organising relief societies in peacetime to assist wounded soldiers in times of war lay the much grander ambition of humanising wars. While falling short of pacifism, this ambition may still sound like a very idealistic one. However, its actual implementation was carried out in a very focused and pragmatic way: through the creation of a network of national relief societies which were independent yet aligned towards the same goal, and through international legal codification.

\section{The capacity to develop, adapt, and deliver through 150 years of conflicts}

Many concepts, methods, and approaches that are today perceived as typical of modern times were already very much present in the original thinking and method of the founders of the ICRC. Some of these also explain the capacity that the Movement has demonstrated over time to adapt and learn lessons from the past and innovate while working in extreme circumstances. We will highlight five of them here.

\section{Dialogue, persuasion, and humanitarian diplomacy}

First, the foundation of the Red Cross illustrates the modern idea of the power of civil society in promoting international solidarity. The publication of A Memory of Solferino and the convening by a committee of private citizens in a provincial city of the International Conference of States in October 1863, which led to the creation of the Movement, was a true humanitarian advocacy campaign. It prefigures the role of modern civil society in setting or influencing the agenda not only of national but also of international politics. The ICRC and its partners in the Movement have accumulated extensive experience in 'humanitarian diplomacy' over the years. ${ }^{9}$

Henry Dunant did not have a Twitter account back in the day, but nevertheless made full use of the communication tools of the time and of networking to spread his ideas and address those in power. International solidarity would later on quickly grow with the evolution of modern communications, starting with the telegraph. ${ }^{10}$

8 After having established the Movement in a first international conference in October 1863, the Committee convened states to meet again in Geneva to adopt a first international treaty to protect wounded soldiers on the battlefield and establish the neutrality of medical staff (the original Geneva Convention of 22 August 1864).

9 See Marion Harroff-Tavel, 'The humanitarian diplomacy of the International Committee of the Red Cross', in African Yearbook on International Humanitarian Law, 2006, pp. 1-16, available at: www.icrc. org/eng/resources/documents/article/other/humanitarian-diplomacy-articles-040310.htm.

10 In 1867, Louis Appia and Gustave Moynier would write about the public realisation of the need to regulate warfare: 'The increasing rapidity, the very instantaneousness of communications, has favoured this awakening; for by this means we live much more in the intimacy of the army than we formerly did.' In 
Because of his direct experience of the battlefield, Dunant could convincingly engage with the political leaders of the time. The ICRC's engagement in action and its proximity to those who need assistance give the organisation its legitimacy when it speaks on behalf of victims of violence. These factors are also a precondition for its relevance and ability to propose innovative practices and responses in terms of humanitarian practices or development of the law.

Although it was created out of public outcry, over the years the ICRC has chosen to develop direct and confidential dialogue as its privileged method of engagement with its interlocutors. This approach, which is at the core of the organisation's identity, has been questioned often and is subject to growing doubt in an international environment demanding greater transparency. However, bilateral and confidential dialogue has proven its effectiveness from the humanitarian point of view. It is a key argument for obtaining access to the people the ICRC assists and protects. It is nevertheless not unconditional or definitive. In its dialogue with the authorities, the ICRC ensures that its approach is contingent on progress being made and on the quality of the dialogue in which it is engaged. ${ }^{11}$

\section{Principled approach to action, enabling access to people in need}

The 1864 Geneva Convention established for the first time rules guaranteeing neutrality and protection for wounded soldiers, field medical personnel, and specific humanitarian institutions. In the aftermath of the Second World War and informed by the Cold War environment, the ICRC, led by Jean Pictet, established a coherent vision of the principles underlying the various activities of the ICRC and the Movement as a whole. The official version of the Fundamental Principles of the Red Cross and Red Crescent Movement was adopted in 1965 at the 20th International Conference of the Red Cross and Red Crescent in Vienna. ${ }^{12}$ The principles of humanity, impartiality, independence, and neutrality have largely inspired the wider humanitarian sector.

For the ICRC, ensuring that parties to a conflict understand that it is independent of political pressure (notably thanks to the diversity of its sources of funding on the one hand and the mono-nationality of its governance, composed only of Swiss citizens, on the other), does not take sides, and is only interested in protecting and assisting impartially those suffering the consequences of armed conflict or other situations of violence is the key for securing access. As Fiona Terry writes, 'remaining neutral in conflict is not a moral position, but simply the most

substance, this quote would not be out of place in the mouth of an Internet-age guru. See A. Appia and G. Moynier, above note 1, p. 519.

11 See 'The International Committee of the Red Cross's (ICRC's) confidential approach', in International Review of the Red Cross, Vol. 94, No. 887, 2012.

12 The Fundamental Principles are available at: www.icrc.org/eng/resources/documents/red-cross-crescentmovement/fundamental-principles-movement-1986-10-31.htm. They were later elaborated upon in greater detail by Jean Pictet in 1979 in the Commentaries written to accompany them. 
effective basis found to date on which to negotiate access to people in need of humanitarian assistance, wherever they are.'13

If neutrality and independence are largely tools to secure access to all communities in need, impartiality and humanity represent the essence of humanitarian philosophy. None of these principles can be compromised.

Since its birth, the ICRC has been quite vocal in upholding the need for principled humanitarian action in order to bring relief to those in need during armed conflict. These principles express the core values binding together the components of the Movement, but they also have a practical operational dimension. Over time, the principles have represented a key point of reference for addressing the dilemmas of humanitarian action and the constant risk of instrumentalisation of aid by political actors.

Today there are many more international organisations and NGOs involved in international solidarity, development or humanitarian work than 150 years ago. However, still very few humanitarian organisations are capable of operating in conflict areas. The ICRC believes that strict adherence to its principles and the backbone provided by a developed and periodically updated internal policies ('doctrines') remains key for reaching people in need.

\section{The power of the law}

To this day, IHL and its implementation mechanisms continue to develop, adapting to the changing realities of conflicts. To this day, the combination of providing humanitarian relief in favour of victims of armed conflict and other situations of violence and reaffirming and developing the law applicable in those situations remains one of the main specificities of the ICRC. This constant process of providing relief and protection based on the proximity the ICRC and the Movement have with those in need could be well illustrated by the quote of André Malraux in L'Espoir: 'transformer en conscience la plus grande expérience possible'. ${ }^{14}$

While the progressive development of the law regulating armed conflicts has been a constant since the adoption of the First Geneva Convention, it also remains a highly sensitive enterprise. This is partly due to the ever-present unfaltering tension between state sovereignty, security, and military considerations on the one hand, and humanitarian considerations on the other. Periods of progress have alternated with periods of stagnation and even sometimes questioning of previous achievements.

This is why ensuring the development of the law and new legal protection mechanisms requires constant vigilance in view of the ever-changing realities of warfare and weaponry. One can count a number of successes of the ICRC in this regard, either on its own initiative or together with other actors of the international community: from the adoption of the Geneva Conventions of 1949 and their

13 Fiona Terry, 'The International Committee of the Red Cross in Afghanistan: reasserting the neutrality of humanitarian action', in International Review of the Red Cross, Vol. 94, No. 881, 2011, p. 187.

14 André Malraux, L’espoir (in English, 'Man's Hope'), Éditions Gallimard, Paris, 1937. 
Additional Protocols to more recent conventions such as the Ottawa Treaty of 1998 or the 2008 Convention on Cluster Munitions.

Two other projects worthy of note include the ICRC study on customary IHL published in 2006, which is accompanied by an online customary IHL database, ${ }^{15}$ and the project to update the Commentaries to the Geneva Conventions and the Additional Protocols, currently underway. ${ }^{16}$

The founders of the ICRC realised the ambivalence of scientific and technological progress, both as a risk and as an opportunity for mankind. The ICRC and the Review maintain the same vigilance today as illustrated by the Review's recent issue on 'New technologies and warfare'. ${ }^{17}$ But ensuring the development of the law is also about avoiding setbacks and preserving the fragile progress achieved. In 1868, already, the ICRC had to resist suggestions to renegotiate entirely the 1864 Geneva Convention! ${ }^{18}$ The ICRC needs to reaffirm the law every time the legitimacy or relevance of the existing law is put into question. During the last decade following the attacks in the United States on 11 September 2001, the declaration by the United States of a 'war against terror' caused new questioning of the progress and relevance of the law. The ICRC stood firm during difficult negotiations with the United States on issues such as the treatment of detainees in Guantanamo. ${ }^{19}$

\section{The power of humanity}

Dunant's dream unleashed 'the power of humanity'. ${ }^{20}$ The main intention of the founders of the ICRC was to facilitate the creation of a national mechanism in every country, which would be independent from government authorities so as to maintain its capacity to deliver assistance impartially. Thus 1863 marks not only the birth of the ICRC but also the birth of what is known today as the Movement: the National Societies, the International Federation of Red Cross and Red Crescent National Societies, and the ICRC. ${ }^{21}$

The strength of the Movement resides in its local anchoring and the commitment of its 97 million volunteers, members, and employees in 187 countries. ${ }^{22}$ Such a diverse membership ensures not only proximity to victims but also efficiency in the assessment of their needs. Today big international humanitarian actors, such as some United Nations agencies or international NGOs, are increasingly aware of

15 The database is available at: www.icrc.org/customary-ihl/eng/docs/Home.

16 See Jean-Marie Henckaerts, 'Bringing the Commentaries on the Geneva Conventions and their Additional Protocols into the twenty-first century', in this issue.

17 International Review of the Red Cross, Vol. 94, No. 886, 2012.

18 C. Moorehead, above note 1, p. 58.

19 See the opinion piece by John Bellinger in this issue.

20 'The power of humanity' was chosen in May 1999 as the slogan for Red Cross Red Crescent activities worldwide; see: http://w3.ifrc.org/what/values/power.asp.

21 The first National Society was created in 1863 in Wurttemberg. See Stefanie Haumer's article, in this issue. The International Federation of the Red Cross and Red Crescent Societies was created in 1919.

22 See the Federation website at: www.ifrc.org/en/who-we-are/the-movement/. The Movement also has its own website, available at: www.redcross.int. 
the need to find local partners and develop local capacities to respond to crises. This capacity has always existed within the Movement and represents a great asset in today's multipolar world. In many contexts, the work of the ICRC would simply be impossible without the mobilisation of the volunteers and staff of the National Societies. Furthermore, the Movement is well equipped to provide the multifaceted responses needed in today's complex, long-lasting crises.

Faced with pressures from governments, or sometimes solicited to become part of integrated international humanitarian responses, the Movement needs to maintain its cohesion around its fundamental principles. Keeping and developing the spirit of partnership within the Movement is essential if the ICRC is to tackle the complexity of humanitarian needs with which it is faced today.

\section{Learning from past experiences}

The 150th anniversary of the ICRC gives the institution an opportunity to look back and reflect on past experiences. The history of the Red Cross is so rich that some of the most creative solutions for today's challenges can also be found in lessons from its past. Critically reviewing one's own history and current practice on a periodic basis is a healthy exercise. The very strengths of organisations can become their own weaknesses: while a clear mandate allows focused action, its narrow reading can also lead to an organisation losing sight of the ultimate objective of the humanitarian endeavour. This has already been the case in the past - as the President of the ICRC, Peter Maurer, has said, the ICRC 'lost its normative compass' when it failed to do its utmost to protect the Jewish and other civilian victims of Nazi persecution during the Second World War. ${ }^{23}$

\section{Today's challenges}

In its 150th year, the ICRC is confronted with a world that is quite different from the one in which it was conceived. Just like in the 1860 s, our world is undergoing great transformation, whether in terms of scientific and technological progress, social relations, the emergence of new regional powers, or the changing nature of violence and conflicts. ${ }^{24}$ Yet, while there are recurrent humanitarian problems, the realities of conflicts continue to evolve and the ICRC is facing new types of challenges. With the growing exposure to public scrutiny, the demands of donors, and the development of the organisation and the humanitarian sector in general, there is a push towards professionalisation. This professionalisation has to be adapted to the humanitarian mandate, as it will ultimately be measured not by increased adhesion to corporate practices but by efficiency and innovation in the fulfilment of that mandate.

23 See the speech given by ICRC President Peter Maurer at the International Tracing Service in Bad Arolsen, 19 November 2012, published in this issue.

24 For more information on the current reading of the humanitarian challenges by the ICRC, see Claudia McGoldrick, 'The future of humanitarian action: an ICRC perspective', in International Review of the Red Cross, Vol. 93, No. 884, 2011, pp. 965-991. 


\section{Frequency and complexity of humanitarian crises}

While new challenges constantly arise, the unpredictability of humanitarian crises has remained their most predictable feature. The need to be ready for rapid response, to perpetually adapt to new humanitarian challenges, and to learn from mistakes and tirelessly and critically question one's own beliefs and practices has been a constant necessity in the history of the humanitarian sector. Already in 1862, Henry Dunant remarked:

[I]n this age when surprise plays so important a part, is it not possible that wars may arise, from one quarter or another, in the most sudden and unexpected fashion? And do not these considerations alone constitute more than adequate reason for taking precautions against surprise? ${ }^{25}$

It is the rising number of crises, their duration and the growing complexity of the needs of affected populations that represent perhaps the biggest new challenges for humanitarian actors: climate change can lead to more frequent large-scale disasters, including in urban areas, which are now much more densely populated than in the past; growing inequalities will continue to fuel injustice and violence, and state oppression can lead to more internal crises and violence. In countries affected both by armed conflicts and natural disasters, the convergence of economic, political, and environmental crises can lead to catastrophic results.

\section{Access and acceptance}

While needs are on the rise, access to victims in conflict- and violence-affected areas remain a major challenge. On the one hand, attempts to subordinate international humanitarian action to military and political agendas persist and one can observe an increasing assertiveness of states in controlling the delivery of humanitarian relief. On the other hand, humanitarian actors need to interact with non-state armed groups. Such groups have become increasingly fragmented in recent conflicts, which adds to the complexity of dialogue with them.

In post-colonial contexts as well as in the current climate of religious radicalisation, the universality of core humanitarian values is put into question not just by governments and armed groups but also by populations. These values are often perceived as imported concepts and rejected as such. To be accepted, the ICRC needs to be trusted as a partner of choice by all. As Claudia McGoldrick writes:

The imposition of 'universal' principles and technical solutions devised by Western academia will be met with increasingly stiff resistance. There is a need for better dialogue with local authorities and affected communities, and for the promotion of principled but not standardized solutions. ${ }^{26}$ 
Faced with this combination of growing needs and lack of access, the biggest frustration for humanitarians is that, contrary to the nineteenth century, the world would have now medical or technological solutions to offer to the populations in need, should the political will be there. In the current absence of global governance and still waiting of new regional powers to fill the gap, there is a tendency towards the containment of conflicts rather than their resolution or prevention. This has put humanitarian actors under growing pressure, with humanitarian action attracting disproportionate attention in the absence of credible political solutions.

\section{Challenges to international humanitarian law}

Despite the undeniable constant progress of its legal protection tools and enforcement machinery, one can still witness blatant disregard for IHL in many contexts. In particular, the ICRC has recently alerted the world to the widespread erosion of respect for medical staff, facilities, and vehicles, with tragic consequences for the health of affected populations. ${ }^{27}$ Sadly, just like at Solferino, the basic protection and care for the wounded and sick is again at the centre of humanitarian and legal concerns. The Review will devote its next issue to this subject.

For the ICRC, the main areas for legal developments today include the protection for persons deprived of their liberty in relation to non-international armed conflicts, and the ways of enhancing and ensuring the effectiveness of mechanisms of compliance with IHL. ${ }^{28}$

The discrete yet key role that the ICRC plays in spreading knowledge of IHL and supporting its integration into domestic legislation, military training, and civil education is more needed than ever. ${ }^{29}$ It asks in particular for even deeper reflection and work in the field of effective influence on the behaviour of belligerents. Just as new technologies allow for increased military capabilities, they also allow for qualitative change in IHL-related prevention activities. In particular, online training as well as military virtual reality simulators have the potential to greatly improve education and training efforts. ${ }^{30}$

Given that most conflicts today are non-international, engaging with nonstate armed groups will continue to prove essential. Thanks to its long-standing practice of dialogue with all parties to conflicts, the ICRC has accumulated a huge amount of experience in dealing with non-state armed actors. Capitalising on this expertise will be critical in continuing to secure access to victims of armed violence.

27 For more information, visit the ICRC website at: www.icrc.org/eng/what-we-do/safeguarding-health-care/ index.jsp?cpn=hcid.

28 For more information and background documents, visit the ICRC website at: http://www.icrc.org/eng/ what-we-do/other-activities/development-ihl/strengthening-protection-victims-armed-conflict.htm.

29 See 'International Committee of the Red Cross: prevention policy', in International Review of the Red Cross, Vol. 91, No. 874, 2009, pp. 415-430.

30 Ben Clarke, Christian Rouffaer and François Sénéchaud, 'Beyond the Call of Duty: why shouldn't videogame players face the same dilemmas as real soldiers?', in International Review of the Red Cross, Vol. 94, No. 886, 2012, p. 714. 


\section{A special issue of the Review}

This issue is also an occasion to remember the origin of the Review - or the Bulletin international des Sociétés de la Croix-Rouge, as it was called at the time was first published by the ICRC in $1869 .{ }^{31}$ For decades, the Review was a mirror of the major concerns of the ICRC and of National Red Cross Societies and published a great deal of information on their activities. Its archives are a unique testimony to the development of the Movement and of humanitarian action in general. The entire collection has been digitalised and is now available online, distributed by Cambridge University Press. ${ }^{32}$

The Review first asked Peter Maurer, the new ICRC president, for his vision for the future of the organisation. We then asked ten privileged witnesses of the contemporary work of the organisation-coming from various continents and backgrounds - to give their perspectives on the significance of this anniversary. They give their frank and constructive assessment of the ICRC and the contemporary challenges to humanitarian action.

The second part of this issue's contents is devoted to the study of selected key moments in the history of the organisation, with various contributions from historians.

The Review then turns to current practice and challenges, giving the floor to ICRC practitioners to illustrate some of the contemporary challenges and approaches in the field of detention, tracing missing persons, and addressing the consequences of violence such as in Northern Ireland.

The ICRC has been permanently present in Israel and the Occupied Territories since 1967. Faced with an absence of dialogue on three core occupation policies (the annexation of East Jerusalem, the settlements, and the routing of the West Bank Barrier), the ICRC has decided to engage in a public debate over these issues. This debate is initiated in this issue of the Review with an article by ICRC's president Peter Maurer and a response piece by Ambassador Alan Baker, former legal adviser of Israel's Ministry of Foreign Affairs.

Beyond this issue, the Review has engaged in a series of events and discussions, such as web seminars and conferences, to reflect on the evolving humanitarian challenges. ${ }^{33}$

31 The publication of the Bulletin was mandated by the Berlin Conference of 27 April 1969, convening the International Committee of the Red Cross, government representatives and delegates from the established National Societies at the time. See Bulletin international des Sociétés de Secours aux Militaires Blessés, No. 1, Le Comité International, Soullier \& Wirth Publ., Geneva, October 1869, p. 4.

32 See http://journals.cambridge.org/action/displaySpecialPage?pageId=2156.

33 For regular updates, visit the Review webpages on ICRC.org or subscribe to the journal's newsletter; see: www.icrc.org/eng/resources/international-review/index.jsp. 
Beyond the history of the organisation, this anniversary also represents an opportunity to reflect on the contemporary humanitarian challenges to which the world must still respond. Humanitarian organisations are still engaged in a neverending fight to secure safe access to victims and make the laws of war respected. In the conflicts and other situations of violence of the twenty-first century, as in the battlefields of the nineteenth, the question of how to protect people in the hands of their enemies remains fundamental. The tension between progress and barbarity is ever-present.

The human cost of conflicts and violence remains as unacceptable today as ever. The ICRC will continue to strive for humanity. Many people in need remain out of reach due to lack of access and security risks. Beyond humanitarian action, what is needed is the crucial political will to spare civilians and to respect IHL.

What is the significance of an anniversary? 'As for me, I regard the ICRC as having been born on the day that I came to know it', writes Sami El-haj in his contribution to this issue. He is referring to the day an ICRC delegate visited him in his cell in Guantanamo. As for millions of people over the past 150 years, the ICRC was born when it came to visit them in prisons, reunited them with their loved ones, or brought them much-needed family news, food, shelter, water, or medical care. Today as 150 years ago, the core mission remains the same: building respect for the law, saving life, and restoring human dignity.

Vincent Bernard Editor-in-Chief 